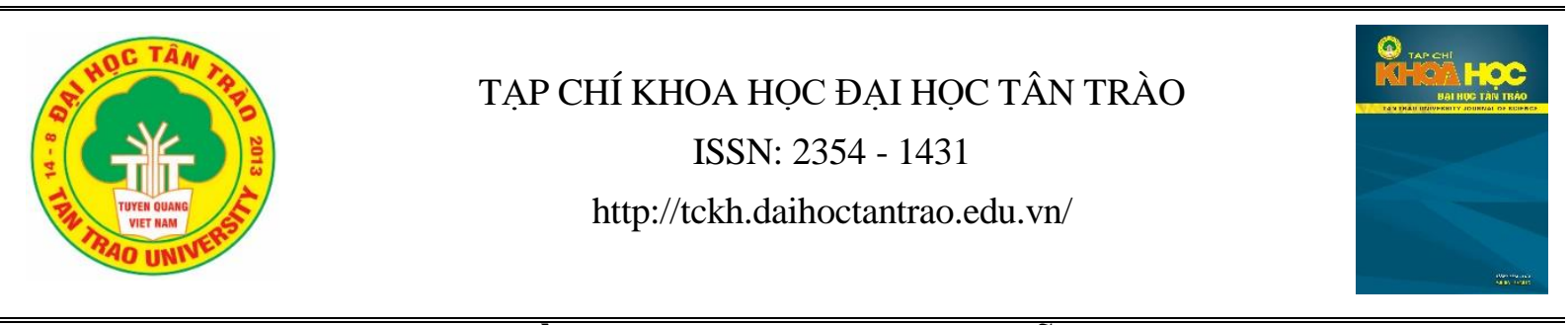

\title{
QUAN Hệ DÒNG HỌ QUA NGHI LỄ TANG MA CỦA NGƯỜI TÀY Ở TUYÊN QUANG
}

\author{
Húa Đúc Hội ${ }^{a^{*}}$ \\ ${ }^{a}$ Trưòng Đại học Tân Trào \\ *Email: huaduchoi@gmail.com
}

\section{Thông tin bài viết}

Ngày nhận bài:

27/2/2020

Ngày duyệt đăng:

10/6/2020

Tù khóa:

Dòng họ, nghi lêe, tang $m a$, người Tày.

\section{Tóm tắt}

Tang ma là một hiện tượng văn hóa tâm linh, đóng vai trò quan trọng trong đời sống văn hóa của tộc người Tày. Ở đó ẩn chứa nhiều giá trị văn hóa trong quan hệ gia đình, dòng tộc nội ngoại, cộng đồng và biểu hiện niềm tin về tôn giáo tín ngưỡng của một cộng đồng ấy. Nghi lễ trong tang ma thể hiện một quy tắc ứng xử giữa cá nhân trong gia đình, dòng họ với cộng đồng. Thế ứng xử đó tạo nên mối giao ước và những quy tắc không chỉ liên quan đến người chết, mà rằng buộc người sống với nhau, buộc con người phải có nghĩa vụ, trách nhiệm với các thành viên trong dòng họ, cộng đồng.

\section{1. Đặt vấn đề}

Theo kết quả điều tra dân số ngày 1/4/2019, tỉnh Tuyên Quang có 784.811 người ${ }^{1}$. Trên địa bàn tỉnh có 23 dân tộc cùng sinh sống, dân tộc Tày chiếm khoảng $25 \%$. Ở nông thôn người Tày thường sống tập trung thành từng làng (bản), tạo thành các quần thể riêng, đây là đặc điểm nổi bật của các làng người Tày truyền thống. Còn ở các vùng thành phố, thị trấn họ sống xen kẽ với các dân tộc khác, chủ yếu là dân tộc Kinh. Dân tộc Tày định cư ở Tuyên Quang từ lâu đời, trong quá trình tồn tại và phát triển, người Tày và các dân tộc khác như Kinh, Dao, Sán Dìu,... có sự giao thoa văn hóa lẫn nhau. Trên thực tế, một số hiện tượng văn hóa của dân tộc giao thoa mạnh mẽ, khiến cho các nhà nghiên cứu khó có thể phân biệt được một cách rõ ràng. Mặc dù vậy, một số yếu tố văn hóa của tộc người Tày vẫn tồn tại và có bản sắc khá riêng biệt, trong đó có tang ma.

\footnotetext{
${ }^{1}$ Ban chỉ đạo tổng điều tra dân số và nhà ở trung ương (2019), tr.157.
}

Tang ma của người Tày ở Tuyên Quang được tổ chức theo những cách thức tương đối cụ thể, rõ ràng. Đám tang của người Tày phải trải qua nhiều nghi lễ bắt buộc như nghi lễ mời thầy cúng; lễ khâm liệm, nhập quan; lễ phát tang; lễ đưa ma, hạ huyệt, cúng 49 ngày, 100 ngày, giỗ đầu, mãn tang. Mục đích nhằm đảm bảo nguyên tắc ích âm, lợi dương; một mặt đền đáp công ơn sinh dưỡng, mặt khác làm hài lòng người đã chết để phù hộ con cháu bình an. Thông qua những nghi lễ này mối quan hệ trong dòng họ, cộng đồng thôn bản càng thắt chặt hơn.

\section{Nội dung nghiên cứu}

\subsection{Một số vấn đề co bản về tang ma của người} Tày

Tang ma là "phức hợp các nghi lễ tôn giáo, tín ngưỡng gắn liền với người chết và các quy tắc ứng xử của gia đình, cộng đồng người sống dành cho người chết"2. Ở người Tày cũng như nhiều dân tộc khác, việc

\footnotetext{
${ }^{2}$ Nguyễn Thị Ngân (2011), tr.28.
} 
tổ chức tang ma trước hết là để đưa tiễn linh hồn của người quá cố sang thế giới bên kia cũng như chuẩn bị cho họ mọi thứ cần thiết cho cuộc sống, sinh hoạt hàng ngày. Từ nhà cửa, ruộng đất, trâu, bò, quần áo, đồ ăn, thức uống, tiền bạc... Đồng thời việc làm tang ma còn nhằm mục đích xoá sạch mọi tội lỗi mà lúc sinh thời người ta phạm phải, giúp cho linh hồn của họ chóng được siêu thoát để tiếp tục một cuộc sống an nhàn, no đủ, sung túc ở thế giới bên kia. Ngoài ra tang ma còn là một dịp, một cơ hội hiếm có để con cái báo hiếu, trả nghĩa, đền đáp công ơn sinh thành dưỡng dục của cha mẹ. Vì thế, tang ma của người Tày thường được tổ chức linh đình, kéo dài trong nhiều ngày với những nghi lễ rườm rà, phức tạp, tốn kém. Chi phí cho đám ma khá lớn, vượt quá khả năng kinh tế của nhiều hộ gia đình và do đó từ xưa đến nay, tang ma luôn là một gánh nặng, nhất là đối với những gia đình có hoàn cảnh khó khăn, hộ nghèo. Để nói về điều đó người Tày có câu nói: "Ba đêm làm ma, ba năm trả nợ" (Slam hằn hắt phi, slam pi chá nỉ). Vì vậy, trong tang ma của người Tày luôn phải có sự trợ giúp về cả vật chất, tinh thần từ anh em trong dòng họ cũng như cộng đồng thôn bản.

Những nghi lễ được coi là quan trọng bậc nhất như vào đám hay đưa tang bao giờ cũng bắt đầu vào ngày tốt, giờ lành. "Chính vì phải chờ đến giờ tốt, ngày tốt mới được phép đưa tang nên trước đây hình thành tập quán quản xác chết trong nhà lâu ngày, ít vài ba hôm, nhiều có thể tới mười ngày, nửa tháng, thậm chí có những trường hợp kéo dài cả một tháng trời”’3. Cũng do việc chọn ngày mai táng mà đôi khi người ta phải áp dụng cả hình thức "tiền táng, hậu tế", nghĩa là nếu chết vào đúng ngày tốt thì xác chết được chôn cất ngay trong ngày, hoặc ngày kế tiếp và một thời gian sau người chết đã nằm yên dưới mồ thì mới tiến hành ma chay, tế lễ. Hoặc một số gia đình do hoàn cảnh kinh tế quá khó khăn hoặc chưa kịp chuẩn bị đầy đủ các thứ cần thiết cho tang lễ cũng cho mai táng người chết trước, sau này khi có điều kiện mới tổ chức đám ma. Điều đó cũng phản ánh việc thực hiện nghi lễ tang ma của người Tày là tốn kém về kinh tế, nên việc thực hiện tang ma nhiều khi là do điều kiện kinh tế - xã hội quyết định. Từ khi Nhà nước ban hành quy định về việc cưới, việc tang, ngày lễ, ngày hội thì đám ma của người Tày đã được tổ chức đơn giản hơn, thời gian thực hiện nghi lễ cũng được rút ngắn, thường gói gọn trong một hoặc hai ngày đêm. Qua khảo sát người Tày ở huyện Hàm Yên, tỉnh Tuyên Quang (xã Bằng Cốc, xã Nhân Mục), đám ma

${ }^{3}$ La Công Ý (2010), tr.286. thường diễn ra trong một hoặc hai ngày đêm (làm ma tươi), nếu những người bị chết bị bệnh truyền nhiễm thì cũng mang đi an táng trong vòng 24 giờ, rồi về tiến hành làm các nghi lễ luôn (làm ma khô). Còn đối với người Tày ở huyện Lâm Bình, tỉnh Tuyên Quang (qua khảo sát xã Hồng Quang, xã Thổ Bình, xã Bình An), đa số người chết thường được chôn cất ngay (không phát tang) sau một thời gian mới tiến hành làm lễ tang (phát tang), một số gia đình hiện nay cũng tiến hành các nghi lễ luôn (làm ma khô) ${ }^{4}$. Điều đó phản ánh một thực tế rằng tồn tại xã hội của người Tày trước đây do điều kiện kinh tế - xã hội còn thấp nên không thể chuẩn bị đầy đủ vật chất cho tang lễ mà cần một thời gian chuẩn bị nhất định, cần sự trợ giúp từ dòng họ, thôn bản đặc biệt là những gia đình có hoàn cảnh kinh tế khó khăn.

Những gia đình người Tày trước đây và bây giờ khi trong nhà có người già yếu hoặc đau ốm kéo dài, bệnh tình mỗi ngày nặng hơn, khó có qua khỏi, người ta có thể làm sẵn một cỗ quan tài để phòng xa lúc lâm sự đỡ phần bối rối, cả nơi chôn cất nhiều khi những người già cũng đã dặn con cháu khi chết thì chôn ở đâu. Việc đóng quan tài đối với những người chưa chết thì thường phải được đóng vào ngày giờ tốt và phải tiến hành thắp hương trên bàn thờ tổ tiên với ý nghĩa trình báo sự việc. Điều đó chứng tỏ người Tày có niềm tin vào mối quan hệ của dòng họ mình giữa những người đang sống với người đã chết (tổ tiên của mình ở thế giới bên kia). Sau khi làm xong nếu chưa cần đến thì cứ để đấy, có thể tạm dùng vào một công việc gì đó nhưng tuyệt đối không cho mượn và càng không thể đem bán. Vì vậy, có những trường hợp đóng áo quan lúc 60 tuổi nhưng thọ gần hoặc trên 100 tuổi nên áo quan cũng bị hỏng nên phải đóng áo quan mới.

Người Tày quan niệm, khi người thân trút hơi thở cuối cùng là lúc chia tay với thế giới trần gian để về cõi âm. Lúc này, gia đình người quá cố thông báo với trưởng họ, bà con họ hàng nội, ngoại và cử người đi mời thầy cúng để làm các thủ tục tiễn đưa linh hồn của người đã chết về nơi an nghỉ cuối cùng được suôn sẻ. Cùng với tổ chức hàng phường của thôn bản, trưởng họ sẽ phân công công việc cho từng thành viên cụ thể trong dòng họ. Ma chay là một công việc bất thường trong đời sống của từng gia đình, nên khi trong dòng họ có người chết, các gia đình cùng họ hàng nhất thiết phải có sự tương trợ giúp đỡ cả về vật chất và tinh thần.

Theo quan niệm của người Tày, nếu trong họ hàng có người chết, gia đình nào trong họ tộc không đến nhận

${ }^{4}$ Hứa Đức Hội (2018), tr 38 
tang, coi như gia đình đó đã từ bỏ quan hệ về dòng máu, tổ tiên trong dòng họ. Bởi vậy, khi trong họ có việc ma chay, các gia đình trong họ đều giúp đỡ tang chủ, gia đình có nhiều giúp nhiều, có ít giúp ít, có thế nào giúp vậy, có thể là vài cân gạo, chai rượu, bó củi, con lợn, con gà và thậm chí cả tiền, các đồ vật cần trong tang lê̂... nhưng trước hết đó là sự quan tâm về mặt tinh thần, hành động, trách nhiệm của những người cùng dòng họ đối với gia quyến. Tuy nhiên, trách nhiệm chính trong đám ma phải thuộc về con cái của những người đã quá cố, đặc biệt là người con trai trưởng (bài viết này chỉ nghiên cứu trường hợp tang lễ thông thường mà không nói trường hợp chết bất đắc kỳ tử, hoặc các trường hợp khác...). Theo tập quán cổ truyền, các con trai, con gái, khi cha mẹ qua đời phải tận tâm, gắng sức lo liệu xong xuôi công việc tang lễ cho cha mẹ để khỏi có tiếng đồn đại về sau và như vậy mới giữ được trọn chữ hiếu với cha mẹ.

\subsection{Quan hệ dòng họ qua các nghi lễ chính trong tang ma của người Tày}

Dòng họ là "toàn thể những người cùng huyết thống, cùng tổ tiên. Tính huyết thống được tính theo bên bố, họ bên nội, người Tày gọi là pạng nả, còn những người thuộc bên mẹ, họ bên ngoại gọi là pạng lăng" 5 .

Khi nhận thấy người thân của mình trong dòng họ ở trong tình trạng hôn mê sâu, có dấu hiệu sắp lìa trần, người ta đem những bộ quần áo mới, đẹp nhất mặc vào cho họ. Tiếp đó họ nhét vào miệng những đồng xu hoặc đặt vào tay người chết coi đo là tiền hành sai khi qua cầu và phủ lên mặt xác chết một miếng vải trắng hay một tờ giấy bản với 03 lỗ thủng ở các vị trí tương ứng với hai mắt và chóp mũi được tạo ra bằng cách dùng nén hương đang cháy châm vào đó. Xác chết được đặt tại khu vực phía trước bàn thờ theo cách quay đầu về phía bàn thờ, được che đi bằng cái màn mà họ vẫn dùng lúc còn sống, tuy nhiên cái màn lúc này được mắc bằng 3 góc (hai góc phía đầu và một góc phía chân). Những công việc này thường là con cái hoặc anh chị em ruột, cháu nội, ngoại... làm, (trường hợp người chết là con, cháu trong khi bố mẹ và ông bà vẫn còn sống thì xác chết đặt ra gian nhà bên ngoài mà không đặt trước bàn thờ tổ tiên của gia đình) dưới sự chỉ đạo của trưởng họ hoặc những người có uy tín, am hiểu về phong tục lễ nghi trong dòng họ. Đồng thời gia đình tang quyến báo lên người đứng đầu thôn bản về việc gia đình có người chết để người đứng đầu thôn bản cùng gia đình phối hợp tổ chức lễ tang theo đúng phong tục của địa phương. Sau khi người đứng đầu thôn bản nắm được thông tin gia đình có người chết sẽ báo cho các hộ gia đình trong thôn, bản biết, để cử người đến giúp gia đình tang quyến cả về vật chất và tinh thần. Vậy, quan hệ dòng họ ở đây không chỉ biểu thể hiện qua mối quan hệ giữa các thành viên trong dòng họ mà còn là mối quan hệ dòng họ với các thành viên trong thôn bản trong việc tổ chức thực hiện các nghi lễ tang ma của người Tày.

Lễ cúng com đầu tiên với lễ vật là một con gà nhỏ và một bát cơm. Gà được đem mổ rồi luộc chín còn bát cơm cúng được tạo thành bằng cách xới 2 bát cơm đầy rồi úp vào nhau, trên miệng bát cơm đặt một quả trứng gà luộc đã bóc vỏ và cắm hai cái que nhỏ dài khoảng một gang tay, trên đầu mỗi que là những sợi phoi vót cong và xù ra giống như chùm hoa mía giờ. Trên bàn thờ thì những bát hương gia tiên phải dùng nón che đi.

Trong thời gian này thì những người thân trong dòng họ nội, ngoại và bên vợ (hoặc bên chồng) có mặt đầy đủ. Trong đó họ nội giữ vai trò quyết định, điều hành công việc, với sự điều hành của trưởng họ hoặc những người có uy tín trong dòng họ (trường hợp trưởng họ không đảm nhận được công việc) gọi tắt là trưởng họ. Sau khi trưởng họ đã họp bàn với các thành viên trong dòng họ nội và đại diện bên họ ngoại, họ bên chồng (hoặc vợ) phân công các công việc để chuẩn bị cho các công việc trong nghi lễ tang ma. Đầu tiên là tìm được vị thầy cúng phù hợp để tiến hành các nghi lễ tang ma cho người chết (thầy cúng phải là thầy Tạo hoặc thầy Phù thủy còn thầy Then, thầy Pụt không có phép thuật cao nên họ không làm đám cúng cho người chết). Sau khi đã tìm được vị thầy cúng thích hợp thì trưởng họ cử một hoặc hai thành viên trong dòng họ đi đón thầy cúng, thường là cháu trai bên nội hoặc con rể. Người đi mời thầy cúng phải đảm nhiệm nhiều việc trong quá trình mời thầy cúng như gánh đạo cụ của thầy, sách cúng, quần áo, khăn mũ, giấy bản (hiện nay việc đưa đón chủ yếu thực hiện bằng xe máy hoặc ôtô). Tuy nhiên, vì tình cảm "nghĩa tử là nghĩa tận" đối với gia đình tang chủ nên họ không quản ngại công việc khó khăn. Lúc này, tại nhà tang chủ, con cháu chưa được khóc, chỉ khi nào thầy cúng đến khâm liệm và phát tang xong mới được khóc. Còn đội kèn trống của đám ma thì con cháu không phải trực tiếp đi đón. Khi thầy cúng đến nhà đám thì tất cả con cái (trực tiếp là

${ }^{5}$ Hứa Đức Hội (2018), tr 10. 
con trai trưởng hoặc cháu trai trưởng) người chết phải ra tận ngõ đón chào và lạy thầy 03 lạy để tỏ lòng kính trọng. Thầy cúng đáp lễ bằng cách niệm thần chú và hơ hơ ngón tay trỏ lên đỉnh đầu mỗi người, viết hờ lên đó chữ Phúc với ý nghĩa ban phúc lành cho tang chủ. Thầy cúng dùng phép thuật để thu toàn bộ tà ma xung quanh nhà. Người Tày gọi là đuổi âm binh - phi dữ quanh quẩn ngoài vườn, không để ma cũ bắt nạt ma mới. Với việc làm này có ý nghĩa như dọn đường, tạo môi trường sạch sẽ để cử hành tang lễ. Sau đó thầy cúng mời thánh thần xuống chứng giám, cúng chiêu hồn người chết, phần hồn người chết với người sống không dính vào nhau. Sau đó ta mới tiến hành nghi lễ khâm liệm.

Cùng thời gian này, trưởng họ sẽ bàn bạc với đại diện thôn bản để kết hợp trong phân công việc thực hiện các nghi lễ tang ma như: Thành lập ban tang lễ, công tác hậu cần, đào huyệt mộ, di quan... Ban tang lễ bao gồm: Đại diện thôn bản, đại diện hội phụ nữ, hội người cao tuổi, đoàn thanh niên...của thôn cùng với đại diện gia đình. Công tác hậu cần, đào huyệt mộ, di quan... là những công việc mà thôn bản giúp đỡ. Còn việc thực hiện các nghi lễ tang ma theo phong tục là công việc của gia đình gia quyến, anh em bên nội, bên ngoại cùng tham gia.

Nghi lê̂ khâm liệm. Đây là những nghi lễ đầu tiên mà người thầy cúng thực hiện cho người chết với sự tham gia của anh em dòng họ gần (3 đến 4 đời). Xác chết được rửa qua theo kiểu làm phép với thứ nước "tinh khiết" lấy ở sông, suối hay múc từ dưới giếng lên rồi bỏ thêm mấy cành thanh táo, vài chiếc lá bưởi với ý nghĩa tẩy uế, thanh trần, làm cho linh hồn người quá cố được sạch sẽ, thơm tho, mát mẻ. Anh em bên nội, ngoại, bên vợ (chồng) đứng xung quanh xác chết theo sự chỉ đạo của trưởng họ nhưng không được khóc.

Nghi lễ nhập quan. Khi làm lễ nhập quan thì người thầy cúng phải niệm chú, làm phép để gom hết số hồn vía còn rớt lại vào trong quan tài. Cũng như trong quan niệm của người Việt thì người Tày cũng cho rằng trong khi làm lễ nhập quan thì những ai có tuổi hợp với người chết không nên chứng kiến lễ nhập quan cả anh em bên nội, ngoại và bên vợ (hoặc chồng), vì hồn vía của họ có thể bị người chết kéo vào trong quan tài (cả con, anh chị em ruột, các cháu). Trong lễ nhập quan thì anh em bên nội (con, anh chị em ruột, cháu...) là những người trực tiếp làm lễ nhập quan cho người chết dưới sự điều hành làm lễ của người thầy cúng và trưởng họ. Giờ nhập quan được người Tày rất coi trọng, vì nó không chỉ liên quan đến người chết mà còn liên quan đến cả người sống, do đó người nào không may chết phải giờ xấu (do đó thầy cúng trước khi nhận lời đến đón, thường phải xem giờ nhập quan trước rồi mới báo cho gia đình đến đón). Khi đưa thi hài vào quan tài, thầy cúng đọc một tờ giấy gọi là tờ "phan", trong đó ghi rõ thân thế người đã mất. Trước khi nắp quan tài đóng lại, tờ giấy đó được bỏ vào trong coi như biên bản bàn giao giữa người sống và người chết. Trong nghi lễ nhập quan thì anh em, nội ngoại trong dòng họ thực hiện các nghi lễ theo phong tục thì những người trong thôn bản chuẩn bị cho áo quan vào vị trí, khiêng người chết vào áo quan.... và các công việc khác theo sự phân công.

Trước khi tang lễ chính thức (phát tang) diễn ra thì gia chủ phải chuẩn bị đầy đủ quần áo, tư trang và các loại vật dụng thông thường mà lúc sinh thời người chết hay sử dụng, con cháu còn chuẩn bị chia thêm của cải cho bố mẹ, ông bà dưới dạng đồ hàng mã và các hiện vật mang tính tượng trưng, trong đó trước hết là ngôi nhà táng chụp lên quan tài được làm bằng những đoạn nứa nhỏ ghép lại với nhau, bên ngoài dán bằng giấy màu. Những vật dụng cùng với ngôi nhà táng sẽ được đem đốt khi tiến hành hạ huyệt. Còn những người trong thôn bản giúp gia đình gia quyến bằng củi, gạo, tiền, ngày công theo quy định.

Tang lễ chính thức (phát tang). Đó là khi vị thầy cúng chủ trì buổi lễ cùng với những người phụ việc cho ông ta niệm chú, yểm bùa để trừ tà, giải uế rồi treo tranh thờ lập đàn cúng. Khi lễ phát tang chính thức được diễn ra thì con, cháu... trong dòng họ nội, ngoại những người vai dưới người chết phải đeo tang và "khóc ma". Trước khi mặc áo tang, con cháu phải cầm áo tang đến bên linh cữu của người chết để bái lạy. Tại thời điểm nghiên cứu cho thấy, mối quan hệ giữa các thành viên trong gia đình - dòng họ có thể được nhận biết qua tang phục của đám ma. Con trai (hoặc cháu trai trong trường hợp bố đã chết hoặc không đội tang cho ông được) mặc quần áo trắng lộn trái được khâu rất sơ sài. Đầu quấn khăn tang trắng có hai đuôi dài về phía sau lưng, mũ chụp phía trên được làm từ rơm hay dây chuối bện chặt hình tròn đội trên đầu, chống gậy tre, quấn giấy trắng. Con gái, con dâu mặc áo vải trắng lộn trái, tóc buông xõa phía sau lưng. Con rể mặc quần áo trắng, khăn trắng quấn tròn trên đầu. Các cháu mặc áo trắng hai tay lộn trái, khăn trắng quấn tròn trên đầu. Họ hàng bên họ nội đội khăn tang như con cháu của người quá cố, còn những nguời bên họ ngoại mặc áo tang trắng, đầu quấn 
khăn tang trắng. Kể từ đây, con cháu phải ngồi hai bên quan tài để thụ lễ, không một ai được phép đi lại tùy tiện. Riêng người con trai phải chống gậy đứng túc trực bên linh cữu, thực hiện các nghi lễ theo phong tục và đáp lễ của những người đến viếng. Tiếp đó các nghi lễ khác lần lượt được tiến hành theo một trình tự nhất định, một nghi lễ quan trọng, mang nhiều ý nghĩa nhất là lễ phá ngục và các lễ tế của các con, anh em bên nội, bên ngoại, thông gia, liên gia và hàng phường. Còn những người trong thôn bản sẽ giúp gia quyến công tác hậu cần như: bếp núc, cỗ bàn, tiếp khách, chuẩn bị lễ vật cho gia đình, đào huyệt... Bởi phong tục của người Tày là ai đến viếng đều phải ăn cơm vì vậy, những công việc trên gia đình gia quyến không thể chuẩn bị được mà phải nhờ anh em nội, ngoại, thôn bản từ đó tạo nên mối quan hệ dòng họ, cộng đồng thôn bản thêm chặt chẽ, khăng khít để thực hiện được đám tang trọn vẹn.

Lễ phá ngục kéo dài tù 2,5 giờ đến 3 giờ. Người Tày quan niệm rằng, lúc sống con người ta phạm rất nhiều tội lỗi; đặc biệt là phụ nữ khi hành kinh cũng như chửa đẻ và giặt tã lót cho trẻ em đã thải chất bẩn ra các dòng suối, dòng sông làm uế tạp thuỷ cung, do đó khi người chết, hồn vía của họ bị Diêm Vương bắt giữ và giam vào ngục tối cho đám quỷ dữ tra khảo, trị tội. Vì thế, phải phá bỏ nhà ngục, giải phóng hồn người chết khỏi hàm răng sắc nhọn của sư tử; đồng thời xoá sạch mọi tội lỗi, giúp họ chóng được "siêu sinh tịnh độ", lên "mường trời” sống một cuộc sống sung sướng, an nhàn, no đủ. Lễ phá ngục của người Tày được thực hiện ở ngoài trời. Nhà ngục hình vuông, làm bằng mảnh vải trắng và vàng quây xung quanh 4 chiếc cọc tre, giữa ngục đặt một ngọn nến và đặt bài vị của người chết, 4 ngọn nến tượng trưng cho bốn cửa đông tây, nam, bắc. Thầy cúng niệm chú, làm phép dẫn đầu người nhà tang chủ đi vòng quanh nhà ngục với ý nghĩa lùng sục, tìm kiếm hồn người chết bị giam giữ trong ngục tối, sau đó dùng kích trượng hoặc dao nhọn gạt đổ từng cây nến một tượng trưng cho các cửa ngục lần lượt bị phá bỏ và nhờ đó hồn người chết được thoát ra ngoài. Như vậy, trong lễ phá ngục thì tang chủ cùng các con, các cháu họ nội là những người trực tiếp thực hiện các nghi lễ dưới sự trụ trì của thầy cúng. Đảm bảo linh hồn của người chết được "siêu thoát" sang thế giới bên kia và gặp tổ tiên của dòng họ mình. Tang ma của người Tày, ngoài lễ tế của các con thì dòng họ bên nội và bên ngoại đều phải có một lễ tế đối với người quá cố, đây là một lễ nghi bắt buộc, thể hiện tình cảm tiếc thương của những người trong cùng dòng tộc với người quá cố. Thông thường, con cháu trong họ nội đảm nhiệm các nghi lễ chính của một đám tang những người thuộc dòng họ bên ngoại thu xếp công việc gia đình để đến gia đình gia quyến phụ giúp công việc đến các nghi lễ, công tác hậu cần.... có liên quan.

Ở lễ tế ho nọi, ho ngoại: Tế họ là lễ tế của dòng họ bên họ nội, họ ngoại thể hiện sự đau buồn, tiễn đưa người chết khỏi đời sống thực tại với anh em trong dòng tộc về với tổ tiên của dòng họ mình ở thế giới bên kia. Lễ vật thường có một con lợn $(40-50 \mathrm{~kg}), 1$ con gà, 1 con vịt luộc, xôi, bánh giầy, gạo và vàng hương xếp trước linh cữu. Thầy cúng tiến hành đọc các bài tế lễ theo sách cúng cho con cháu, anh em trong dòng tộc bên nội, bên ngoại nghe. Con cháu, anh em trong dòng tộc quỳ trước linh cữu của người quá cố thụ tang. Sau đó, thầy cúng theo vai vế trong dòng tộc sẽ gọi tên từng người lên trước bài vị thắp hương, rót rượu và vái ba lần trước anh linh của người đã mất. Thầy cúng đọc những lễ vật được dòng họ nội, họ ngoại mang đến để cúng người chết. Lễ vật để tế thường là anh em trong họ góp nhau để cùng chuẩn bị. Điều đó chứng tỏ mối quan hệ dòng họ của người Tày là rất chặt chẽ, có tôn ti trật tự. Gia đình tang chủ mời cơm, nước để chia buồn cùng gia đình tang chủ. Gia đình tang chủ cũng để lại "lộc" cho dòng họ bên ngoại bao gồm: $1 / 4$ con lợn đến viếng, các thứ khác là $1 / 2$. Để sau khi anh em bên nội, bên ngoại viếng xong trở về làm bữa cơm cảm ơn anh em họ hàng đã đến giúp đỡ, phúng viếng, đồng thời đây cũng là dịp để trưởng họ hoặc những người am hiểu về phong tục tập quán của người Tày, dòng họ truyền lại cho thế hệ sau, qua đó thể hiện mối tương trợ về tinh thần, vật chất của dòng họ người Tày.

Lễ tế của thông gia, liên gia: Quá trình thực hiện lễ nghi tang ma, người Tày không chỉ có lễ tế của dòng họ bên nội, bên ngoại mà còn có lễ tế của bên thông gia, liên gia cũng được coi trọng và là lễ nghi bắt buộc với những người đã có con đã dựng vợ, gả chồng. Lễ vật thường là một con gà, một con vịt, gạo tẻ, rượu gạo, vàng mã. Sau đó, mời họ vào lễ trước anh linh người quá cố. Thầy cúng tiến hành đọc bài tễ tiễn biệt người chết và các lễ vật do bên thông gia, liên gia cấp cho người quá cố. Còn con cháu người chết phải đứng thụ tang. Sau khi tham dự lễ tế xong, gia đình bên thông gia, liên gia ở lại ăn cơm, chia buồn cùng với gia đình tang chủ. 
Đối với người Tày ở huyện Lâm Bình, tỉnh Tuyên Quang tại thời điểm chúng tôi nghiên cứu tại xã Hồng Quang thì còn có lễ tế của các cháu gái đã xây dựng gia đình riêng. Lễ vật cũng giống như dòng họ nội, hoặc ngoại nhưng là do các cháu ngoại góp vào để tiến hành lễ tế. Qua đây nó thể hiện trách nhiệm rất lớn của các cháu gái ngoại đối với cội nguồn của mình. Đây cũng là dịp để các cháu thể hiện sự đoàn kết giúp đỡ, tương trợ lẫn nhau cả về tinh thần và vật chất đối với gia đình tang chủ ${ }^{1}$.

Nghi lễ đua tang (slống phi, óc phi). Thầy cúng niệm chú, làm phép nhằm góm nốt số hồn vía người chết còn sót lại vào trong quan tài. Nếu chồng chết trước vợ thì trước lúc đưa quan tài ra khỏi nhà phải làm lễ chia tay. Người vợ cùng con cháu quỳ ở phía chân quan tài, mặt ngoảnh ra cửa, mỗi người cầm một chén rượu và vòng tay đưa ra phía sau lưng. Tiếp đó, các con trai, con gái, con dâu, con rể lấy thân mình "lát đường", "bắc cầu" cho linh hồn bố mẹ đi sang thế giới bên kia. Họ nằm sấp, úp mặt xuống phía dưới, nối đuôi nhau làm thành một hàng dài từ chỗ đặt quan tài ra đến ngõ nhà để khiêng quan tài lên phía trên. Theo phong tục người Tày, khi đưa quan tài ra khỏi nhà (nhà sàn truyền thống) không được đi qua cầu thang lên xuống hàng ngày mà phải làm một chiếc cầu thang tạm bằng cây tươi với số bậc là chẵn. Chiếc cầu tạm này do thôn bản giúp dựng.

Sau khi ra khỏi nhà, quan tài được đặt lên đòn khiêng để đưa đến nơi chôn cất. Thầy cúng niệm chú và tung vài nắm gạo lên mái nhà táng với ý nghĩa bố thí cho những hồn ma không ai thờ cúng rồi mới đưa quan tài đi chôn cất. Dẫn đầu đoàn đưa tang là một người con hoặc cháu cầm bó đuốc đang cháy tượng trưng cho việc soi đường, dẫn lối, đưa linh hồn người chết sang cõi âm. Tiếp đến là một người cầm đồ lễ và tiền vàng làm bằng giấy cắt nhỏ rắc dọc đường từ nhà đến nơi chôn cất với ý nghĩa bố thí cho cô hồn. Theo sau là thầy cúng, họ hàng thân thích cuối cùng là hàng xóm, láng giềng. Khi đưa tang con trai trưởng bao giờ cũng đi phía trước quan tài (phía đầu người chết), con trai thứ đi phía sau (phía chân người chết), cháu, chắt đi hai bên, con gái, con dâu đi ngay phía sau quan tài. Như vậy, trong nghi lễ đưa tang quan hệ dòng họ thể hiện "tôn ti trật tự", thấy được vị thế của người con trai, vị trí của trưởng họ, của các thành viên trong dòng họ theo một trật tự nhất định, không bị đảo lộn.
Nghi lễ hạ huyệt. Trước lúc hạ huyệt, con cháu làm lễ tiễn biệt người chết sang thế giới bên kia, thầy cúng niệm thần chú làm phép "an sơn thần". Tiếp đó thầy cúng làm lễ cúng vong cho người chết trước lúc hạ huyệt. Sau khi lấp huyệt và đắp thành nấm mồ, thầy cúng một lần nữa niệm thần chú, làm phép gom nốt số hồn vía người chết còn rơi rớt lại, đồng thời gọi hồn vía những người tham gia đưa tang về với thể xác. Sau đó là đốt ngôi nhà táng, các thứ hàng mã... cho người chết. Cuối cùng là lấy hòn đá to đặt dưới chân mộ đánh dấu vị trí ngôi mộ và dựng nhà mồ. Trong nghi lễ này con, cháu, anh em bên nội, ngoại là những người thực hành các nghi lễ còn thôn bản là những người giúp gia đình hạ huyệt, đắp mộ....đến khi hoàn thành các công việc trong một đám tang trọn vẹn của gia đình người Tày.

Lễ $m o ̛$ cứa $m o ̂ ̀$ (khay tu mả thực hiện vào ngày thứ 03 tính từ lúc làm lễ phát tang) với ý nghĩa để hồn vía của họ ra mắt sơn thần. Hiện nay lễ mở cửa mồ thường được các thầy Tào và gia đình thực hiện sau khi nghi lễ hạ huyệt kết thúc nhằm giảm bớt thời gian, vật chất... cho gia đình tang chủ.

Khi tất cả các nghi lễ trên đã thực hiện xong "mồ yên, mả đẹp" gia đình tang chủ sẽ làm cỗ mời thôn bản những người đến giúp gia đình. Bữa cơm là dịp để gia đình bày tỏ biết ơn hoặc xin lỗi đến thôn bản, những người đến giúp gia chủ hoàn thành công việc theo đúng phong tục. Qua đó thể hiện mối quan hệ của gia đình, dòng họ, thôn bản ngày càng thắt chặt. Ngoài những lễ nghi trên, tang ma của người Tày còn phải trải qua nhiều nghi lễ khác như: cúng 49 ngày, 100 ngày, giỗ đầu, mãn tang. Nhưng những nghi lễ này chỉ có sự tham gia của gia đình họ nội và ngoại, không có sự tham gia giúp đỡ của thôn bản.

\section{Kết luận}

Quan hệ dòng họ qua nghi lễ tang ma của người Tày ở Tuyên Quang biểu hiện trong những không gian, thời gian cụ thể khi thực hiện các nghi lễ. Khi thực hiện các nghi lễ mối quan hệ giữa những người đã chết, giữa người đã chết với người đang sống, giữa những người đang sống với nhau tạo nên mối quan hệ dòng họ ngày càng bền chặt và bảo tồn, phát huy những giá trị văn hóa truyền thống của tộc người. Thực tế, tang ma của người Tày, trách nhiệm nặng nề thuộc về người con trai trưởng, trưởng họ và dòng họ nội. Trưởng nam phải gánh vác trách nhiệm lễ tế, cõng bài vị, dâng, hóa sớ.... Gia đình nào không có con trai phải nhận một cháu trai

${ }^{1}$ Hứa Đức Hội (2018), tr 47. 
hoặc em chú trong nội tộc gánh trách nhiệm trên. Người cháu hoặc người em chú có trách nhiệm như con trai đẻ trong gia đình, lúc cha, mẹ chết phải chống gậy, chịu tang. Điều đó cho thấy, trong xã hội người Tày, vai trò phụ quyền chiếm ưu thế, nhưng khi gia đình có việc hệ trọng như tang ma, tất cả các thành viên trong gia đình dòng họ, trai cũng như gái đều đồng lòng chịu tang thực hiện nghĩa vụ báo hiếu. Tang ma của người Tày còn cho thấy vai trò của dòng họ nội, họ ngoại đặc biệt là trưởng họ người điều hành mọi công việc trong thực hiện các nghi lễ tang ma, biểu hiện cho sự đoàn kết trong dòng họ và mối quan hệ của dòng họ với cộng đồng thôn bản. Họ ứng xử như những thành viên trong gia đình tang chủ, cùng chia sẻ với gia đình tang chủ thông qua những lễ tế riêng. Điều đó đã trở thành một phong tục, tập quán quan trọng đối với người Tày để sự cố kêt trong dòng họ; dòng họ với thông gia, liên gia, cộng đồng thôn bản.

\section{TÀI LIỆU THAM KHẢO}

1. Ban chỉ đạo tổng điều tra dân số và nhà ở trung ương (2019), Kết quả tổng điều tra dân số và nhà ở thời điểm 0 giờ ngày 01 tháng 4 năm 2019, Nxb Thống kê, Hà Nội.

2. Triệu Quỳnh Châu (2017), Dòng họ của nguoòi Tày ở huyện Bạch Thông, tỉnh Bắc Kan, Luận án Tiến sĩ nhân học, Viện hàn lâm khoa học xã hội Việt Nam, Hà Nội.

3. Hứa Đức Hội (2018), Quan hệ dòng ho trong đời sống tín nguõng của nguời Tày tỉnh Tuyên Quang, Đề tài khoa học và công nghệ cấp cơ sở, Trường Đại học Tân Trào, Tuyên Quang.

4. Nguyễn Thị Ngân (2011), Tang ma của nguoòi Nùng Phàn Slình ở tỉnh Thái Nguyên, Luận án Tiến sĩ Lịch sử, chuyên ngành Dân tộc học, Trường Đại học Khoa học xã hội \& Nhân văn, Hà Nội.

5. La Công Ý (2010), Đến với nguời Tày và văn hóa Tày, Nxb Khoa học xã hội, Hà Nội. 


\section{Lineages relations through funeral rites of the Tay in Tuyen Quang}

Hua Duc Hoi

Article info

Recieved:

27/2/2020

Accepted:

$10 / 6 / 2020$

Keywords:

Lineages, ritual, funeral,

The Tay people.

\begin{abstract}
Funeral is a spiritual cultural phenomenon, playing an important role in the cultural life of the Tay people. There are hidden cultural values in family relationships, paternal lineages, maternal lineages, communities and expression of belief in religious beliefs of that community. Funeral rites represent rules of behavior between individuals in families, lineages and communities. That behavior creates covenants and rules that not only relating to the dead, but also tying the alive people with each other which asks people to have obligations and responsibilities to members of their lineages and the community.
\end{abstract}

